\title{
A Pragma-Stylistic Study of Illocutionary Act in Buginese Drama Texts
}

\author{
Ainun Fatimah ${ }^{1 *}{ }^{*}$ Kamsinah $^{2}$ \\ ${ }^{1}$ Hasanuddin University \\ ${ }^{2}$ Hasanuddin University \\ *Corresponding author. Email: ainunfatimah@unhas.ac.id
}

\begin{abstract}
Bugis language is one of the main regional languages in South Sulawesi Province as well as the fifth-largest regional language in Indonesia, after Javanese, Sundanese, Madurese, and Betawi languages. In this case, Bugis language, apart from being a daily spoken language, is also used in drama communication. In this study, what is analyzed is the use of Indo Safiah's illocutionary speech acts to her five daughters, namely Mira, Meila, Nora, Nina, and Silfi. The purpose of the analysis is (1) to reveal the way Indo Safiah packs her thoughts in various illocutionary forms (stylistic aspects) when interacting with her daughters by sorting them based on the frequency of their appearances and (2) showing the prominent content in each type. illocutionary speech act. The source of data for illocutionary utterances is a Bugis-language drama script entitled Indonesian "Gathering on Mother's Day". The data were analyzed using a pragma-stylistic approach. The results of the study indicate that the speaker (the mother) and the addressee (the child) understand each other's utterances so that there is no miscommunication between them, which means that the use of illocutionary functions is effective. In this case, it is revealed that in the drama script there are 96 types of illocutionary speech acts. The order of the highest frequency is directive illocutionary (39), representative or assertive (29), expressive (22), commissive (6), and declarative (0). The most frequent subtypes of speech acts that appear are confirming and ordering something (directive), informing (representative/assertive), giving thanks (expressive), promising something (commissive), and not finding declarative illocutions. On the other hand, the style of language that is often used is the style of satire, comparison, and affirmation with the dominant diction of the Bugis language.
\end{abstract}

Keywords: Speech, Illocutionary, Drama script, Language style, Bugis language.

\section{BUGIS LANGUAGE IN INDONESIA}

Bugis language is one of the main regional languages in South Sulawesi Province as well as the fifth-largest regional language in Indonesia, after Javanese, Sundanese, Madurese, and Betawi languages. In this case, Bugis language, apart from being a daily spoken language, can also be used in drama communication. In the latter case, it can be seen in the use of language forms of illocutionary speech acts in the Bugis drama script entitled Indonesian "Gathering on Mother's Day".

\subsection{Illocutionary Forms}

The research problem is formulated in the form of questions, specifically how to express how Indo Safiah packs her thoughts in various illocutionary forms (stylistic aspects) when interacting with her daughter in the Bugis drama text entitled "Social occasion on Mother's Day" and also how to express the content that stands out in each type of act. illocutionary speech with a description of the frequency of use of each.

\subsubsection{Stylistic Aspects}

This research was conducted with the aim of: (1) revealing the way Indo Safiah packages her thoughts in various illocutionary forms (stylistic aspects) when interacting with her daughter by sorting them based on their frequency of occurrence, and (2) showing prominent content in each type of illocutionary speech act by description of the level of frequency of use of each. 


\subsubsection{Pragma-Stylistic Approach}

The illocutionary speech data in this study were obtained from a Bugis-language drama script entitled Indonesian, namely "Gathering on Mother's Day". The data were analyzed using a pragma-stylistic approach. In this case, the identification of all forms of speech acts are classified into three types of speech acts, namely locutionary act, illocutionary act, and perlocutionary act. Locutionary speech acts are understood as part of speech acts that have the meaning of stating something, while illocutionary acts are speech acts related to the act. The speech act is related to the content of the meaning of something said. Then, the perlocutionary speech act is one part of the speech act whose focus is to make the hearer motivated to do something.

\section{SPEECH ACT}

In this study, illocutionary speech acts were analyzed using a pragma-stylistic approach, then revealed the data according to the formulation of the problem, the discussion consisted of two main parts, namely (1) types of illocutionary speech acts and (2) frequency of use of each subtype of speech acts. illocutionary.

\subsection{Speech Act}

Speech acts are actions that are performed when speech is spoken. According to Austin in Ainy, (2017: 14) "speech acts are actions that are done in saying something" then speech acts are speech that does not talk about something, also contains real actions such as apologizing, promising, or the like. Levinson (in Meliana [1]) states that in the pragmatic approach, speech acts are phenomena that must be explained using theory.

\subsection{Types of Illocutionary Speech Acts}

There are five types of illocutionary speech acts, namely assertive, directive, commissive, expressive and declarative.

\subsubsection{Assertive}

Assertive speech acts can be described with Mrs Safiah as a speaker bound to the truth she expresses, for example stating, informing, complaining, and reporting.

Example:

(1) "Ettana nappaki maddeppungengsi manre wenni pappada Iyae, marejjing manengki uwita nataro jamangjamang, nancajini toli alalenami indota ri bolae kasi'na!"

(How long it took us to get together again to have dinner together like now, I noticed that everyone was busy with their respective jobs, which made your mother stay at home alone, sorry!)
Data (1) contains the assertive illocutionary state, informs, and at the same time complains about the condition of the speaker who has been in a lonely state for a long time living alone without being visited and gathered with the speaker, namely his daughters, who according to his assessment, the speakers' children are very busy. This is shown by the utterance "ettaa looks maddeppungengsi ..." (how long it took us to get together again); marejjing manengki uwita nataro jamang-jamang (I noticed that everyone was busy with their respective jobs); nancajini toli alalenami indota ri bolae (make your mother stay alone at home, sorry!)

\subsubsection{Directive}

This speech act functions so that the speaker does something or causes a result in the form of an action taken by the speaker. The illocutionary functions include ordering, suggesting, permitting, warning, and affirming as in the example of the speech below:

(2) Naikiya makkukuangnge Indo, engka manengnik maddeppungeng duangngik (However, now we have all gathered to accompany Mother.)

(3) Tegani pale'na Anto Meila, jajima jokka ku bolae? (Then, Anto, where is Meila, did she come to this house?)

Data (2) is a warning directive and data (3) is a confirming directive. In this case, the speaker warns the speaker, Ibu Safiah, that her children are now present and gathered to accompany her. In response to this, the speaker intended to ensure the presence of Meila, one of the speaker's children who at that time had not been seen to be present. In terms of perlocutionary, speech (2) is expected to give a calming effect to the speaker, in this case, the mother.

\subsubsection{Commissive}

This commissive speech act is characterized by the speaker being bound to action in the future, such as the information spoken by the characters in the drama script below:

(4) Hehe, engkanatu, Indo Calonna Silfi, Maelomani onion ipasiruntuki Indo (Hehe, there is Silfi's future husband, Mom, the rest will be met with Mother).

The context of the speech (4) is that Nora tells the mother that Silfi already has a potential life partner. In this context, the mother is given a promise or hope to meet the prospective daughter-in-law, namely by saying, "maelomani onion ipasiruntuki Indo" (the rest will be met with Mother). A similar example can be seen in speech (5) below. 
(5) Makku pale'na Indo. Majjanci manengki toli siselle-selle jokka duangngi (5)

Yes, right? (makkutanai ku sininna rikkanengna)

(Let's just say, Mom, how about we promise to take turns accompanying you. Yes, right)

(Context: Asking all his brothers)

With the story (5) Sandra promised to take turns accompanying her mother while waiting for the approval of all her siblings who were there.

(6) Iyye Indo, God willing. Idi' maneng ana'ta maelo maneng mokki siselle-selle jokka mitaiki, nasaba sukku maneng pappojitta lao ri idi Indo.

(Yes mother, God willing, we all your children are willing to take turns to visit mother because of our full love for mother)

Speech (6) was spoken by Meila -- on behalf of all her siblings -- to her mother as a form of agreement to the promise to take turns taking care of their mother in the future.

\subsubsection{Expressive}

The function of this illocutionary is to reveal the psychological attitude of the speaker to the situation or situation implied in the illocutionary as shown by the information below:

(7) (Context: nasussui uwwai matanna nappa cabberu). Thank God

Degaga uwellau son, tennia warang machete Iyarega pamale iyya indo sappa, Naikiya iyya indomu Iyae maelomi ipoji nak sippadato pappojikku lao ri idi maneng.

Good luck with your sappiseng, Ana sibawa Nina, duangngak. Sibawa de naengka magelli Iyarega macai narekko uwaceri manengngi (wipes her tears and smiles). Thank God.

I'm not asking for anything, son, it's not wealth or favors that I'm looking for, but I want to be loved as I love all of you.

Luckily, there are still your cousins who accompany mom, they never sulk or get angry when I scold them

The context in this case is the speech data (7) spoken by Mrs. Safiah while wiping her tears while smiling with emotion and gratitude. The speaker expresses a moved expression marked by the word "Alhamduliillah" which means that something good is accompanied by gratitude. The utterance contains an expression that is spoken by the speaker to the addressee who feels his love is welcomed, marked by the sentence Naikiya iyya Indomu Iyae Maelomi Ipoji Nak sippadato pappojikku lao ri idi maneng. Thus, it can be concluded that the utterance is an illocutionary utterance of an expressive type.

\subsubsection{Declaration}

The acceptance or success of this illocutionary result in a match between the proposition and the reality, such as appointing an employee, resigning, firing, declaring punishment, baptizing, and so on. This speech act is a very special and rare type of speech act. As shown in this study, there is no single type of illocutionary act of declaration in this Bugis drama script, because this type of illocutionary act belongs to a special category.

On the other hand, it is also revealed that in the drama script there are 96 types of illocutionary speech acts. Based on the frequency, the first (highest) order is the directive illocutionary subtype (39). The details are ordering (17), confirming (9), suggesting (4), prohibiting and giving advice ( 2 each), then reminding, inviting, ordering, permitting, and recommending (1 each). The second order is representative or assertive illocutionary (29). The details are to tell (25), complain (2), then state and boast (1 each). The third order is expressive illocutionary (22). The details are to say thank you (10). As for joy, praising, and apologizing (2 each). Then, giving thanks, criticizing, expressing love, blaming, disappointed, and giving forgiveness (1 each). The fourth-order is the commissive illocutionary (6) with details promising (4) and expecting or asking for prayer (2). Finally, the declarative illocutionary is not found.

In addition, the style of language that is often used is the style of satire, comparison, and affirmation with the dominant diction of the Bugis language. An example of the use of the satire language style can be seen in data (1), namely Indo Safiah insinuating that her children are so busy that they forget their mother. This is revealed through the utterance ettana nappaki maddeppungengsi (how long it took to get together); marejjing manengki uwita nataro jamang-jamang (it looks like you are all busy with your work). The comparative language style is found in data (6) which states that the children's feelings of love and care for the mother are all the same. It was said, "idi' maneng ana'ta maelo maneng mokki siselle-selle jokka mitaiki, nasaba sukku maneng pappojitta lao ri idi Indo (we all your children are willing to take turns to visit mom because we all love mommy). The style of affirmation can be found in data (2) and (5). In data (2) it is emphasized that Naikiya makkukuangnge Indo, engka manengnik 
maddeppungeng duangngik (however, (in fact) now we have all gathered to accompany Mother.) Then, in data (5) it is stated firmly, "Makku pale'na Indo ... (let's face it, Mother).

Based on the results of the analysis of illocutionary acts in the Bugis language drama text entitled "Gathering on Mother's Day", the following conclusions can be drawn. There are 96 types of illocutionary speech acts in this Buginese drama text. The order of the highest frequency is directive illocutionary (39), representative or assertive (29), expressive (22), commissive (6), and declarative (0). The most frequent subtypes of speech acts that appear are confirming and ordering something (directive), informing (representative/assertive), giving thanks (expressive), promising something (commissive), and not finding declarative illocutions. On the other hand, the style of language that is often used is the style of satire, comparison, and affirmation with the dominant diction of the Bugis language. Thus, from a pragma-stylistic perspective, Bugis language is proven to be still very effective in being used in drama dialogues to give mutual understanding, to create harmony and understanding between the speaker and the addressee.

\section{AUTHORS' CONTRIBUTIONS}

The second author provides support for ideas and moral support to the first author.

\section{ACKNOWLEDGMENTS}

The writer would like to thank her parents, husband and kids for their support and also her colleagues in the English Department of Hasanuddin University and their teammates SYM as her supporting system.

\section{REFERENCES}

[1] Meliana, B. (2019). The illocutionary acts of jokowi speech in world economic forum: a pragmatic approach. Makassar: Universitas Hasanuddin 